\title{
PENGARUH PEMBELAJARAN DARING PADA MASA PANDEMI COVID-19 TERHADAP TINGKAT PEMAHAMAN BELAJAR MAHASISWA
}

\author{
Lizha Dzalila Q. A ${ }^{1}$, Annisa Ananda ${ }^{2}$, Saifuddin Zuhri ${ }^{3}$ \\ UPN Veteran Jawa Timur, Surabaya, Indonesia
}

\begin{abstract}
ABSTRAK
Artikel ini bertujuan untuk mengetahui bagaimana tingkat pemahaman belajar pada mahasiswa dalam melakukan pembelajaran melalui metode daring. Jenis penelitian yang digunakan adalah deskriptif kualitatif dengan wawancara mendalam kepada beberapa infoman. Fokus penelitian ini adalah permasalahan komunikasi yang muncul pada saat pelaksanaan pembelajaran daring dan tingkat pemahaman belajar mahasiswa yang dilakukan pada masa pandemic Covid-19. Hasil penelitian ini menunjukkan bahwa dalam pelaksanaan pembelajaran daring banyak ditemukan permasalahan yang menyebabkan semangat belajar dan tingkat pemahaman belajar mahasiswa menjadi menurun.
\end{abstract}

Kata-kata Kunci:Mahasiswa, Pembelajaran Daring, Covid-19

\section{THE EFFECT OF ONLINE LEARNING IN THE COVID-19 PANDEMIC ON STUDENT UNDERSTANDING LEVELS}

\begin{abstract}
This article aims to find out how the level of understanding of learning of students in learning through online methods. This type of research is descriptive qualitative in-depth interviews with informans. The focus of this research is the communication problems that arise during the implementation of online learning and the level of understanding of student learning conducted during the Covid-19 pandemic. The results of this study indicate that in the implementation of online learning many problems are found that cause enthusiasm for learning and the level of understanding of student learning to decline.
\end{abstract}

Keywords: College Student, Online Learning, Covid-19

\section{PENDAHULUAN}

Belajar sudah menjadi kewajiban bagi para mahasiswa. Mencari ilmu, mengasah skill yang dimiliki, dan juga menambah wawasan demi kecerdasan otak. Tentunya belajar merupakan poin utama yang harus dikejar oleh mahasiswa. Terkadang nilai masih menjadi patokan tingkat ukur rajin dan pintarnya mahasiswa. Tak selalu nilai hanya berasal dari hasil mengerjakan tugas dan soal yang diberikan oleh dosen. Terkadang beberapa dosen juga memberi nilai khusus atas etika, sopan dan santun, serta keaktifan mahasiswa 
sendiri. Mahasiswa dituntut dan dilatih agar otak dan wawasan berpikiran luas, terbuka, etika dan tingkah laku dapat dilatih untuk terus menjadi lebih baik, serta bakat dan kemampuan yang terus menerus diasah agar dapat berkembang dari hari kehari yang nantinya dapat berguna baik bagi kepentingan diri sendiri maupun kepentingan banyak masyarakat.

Belajar adalah aktivitas yang dilakukan dalam rangka menambah wawasan dan ilmu yang dapat berguna bagi kepentingan diri sendiri dan orang lain. Manusia melakukan hal ini dalam kondisi sadar dan sengaja melakukannya. Dalam aktivitas belajar akan terjadi perubahan dalam diri seseorang tersebut. Jika perubahan intensitas keaktifan pada jasmani dan mental seseorang berubah menjadi tinggi maka dapat dikatakan sebuah kegiatan belajar tersebut adalah hal yang baik. Hal yang sebaliknya pun sangat memungkinkan dapat terjadi. Dalam hal belajar, seseorang tidak hanya berfokus pada buku atau materi. Belajar juga dapat diartikan interaksi seseorang dengan lingkungan yang ada di sekitarnya. Artinya lingkungan pun dapat memberikan kita informasi dan wawasan yang berguna untuk diri seseorang. Lingkungan disini yang dimaksut adalah ketika obyek atau halhal yang ada di sekitar individu dapat menjadikan seseorang belajar dari pengalaman dan pengetahuan yang pernah ia miliki atau temukan sebelumnya.

Lain halnya dengan belajar, pembelajaran memiliki makna yang lebih condong ke arah proses. Proses bagaimana pembimbing atau dosen dapat mengatur, merangkai, merencanakan, dan mengorganisasikan materi agar menumbuhkan semangat belajar pada peserta didik yang diampu dan mencapai tingkat pemahaman yang diinginkan oleh pembimbing atau dosen.

Pembelajaran merupakan suatu sistem yang kompleks yang keberhasilannya dapat dilihat dari dua aspek yaitu aspek produk dan aspek proses. Keberhasilan pembelajaran dilihat dari sisi produk adalah keberhasilan siswa mengenai hasil yang diperoleh dengan mengabaikan proses pembelajaran. (Sanjaya, 2011:13-14).

Keberhasilan pembelajaran dilihat dari sisi hasil memang mudah dilihat dan ditentukan kriterianya, akan tetapi hal ini dapat mengurangi makna proses pembelajaran sebagai proses yang 
mengandung nilai-nilai pendidikan. Dapat diartikan bahwa kesuksesan seorang pembimbing atau guru dapat dilihat dari dua hasil produk tersebut. Yaitu aspek produk dan aspek hasil. Tidak selamanya kesuksesan dilihat dari aspek hasil. Justru terkadang hasil terbaik terlihat setelah proses yang telah mereka lakukan. Pembelajaran merupakan interaksi dari dari kumpulan komponen-komponen penting yaitu pembimbing atau pendidik, peserta didik, dan sumber pengetahuan yang terjadi dalam satu situasi dan satu tempat. Interaksi yang dilakukan tersebut juga dilakukan dalam keadaan sadar atau memang sengaja dilakukan untuk sebuah tujuan tertentu yang ingin dicapai. Interaksi yang dilakukan bersifat edukatif yang berarti segala interaksi yang dilakukan memiliki tujuan menambah wawasan dan meningkatkan kecerdasan bagi peserta didik. Pembimbing melakukan banyak hal seperti merancang materi, melaksanakan tahap interaksi yang telah dirancang dengan peserta didik, serta mengevaluasi hasil kerja yang telah dilakukan. Pembelajaran tidak bisa terjadi tanpa adanya perencanaan yang baik. Semua interaksi tersebut membutuhkan proses yang melalui tahapan-tahapan. Tahapan-tahapan ini sangat penting diperhatikan detailnya agar hasil yang didapat dapat sesuai dengan hasil yang diinginkan. Ketika hasil yang didapat sudah sesuai atau hampir mendekati hasil yang diinginkan otomatis dapat dikatakan bahwa pembelajaran tersebut merupakan pembelajaran yang baik dan efektif.

Tentunya hasil yang diinginkan adalah sesuatu yang positif atau hal baik yang dapat dirasakan tidak hanya oleh peserta didik, melainkan kedua belah pihak. Pembelajaran adalah hal yang dilakukan melalui proses dan interaksi kedua belah pihak baik peserta didik maupun pembimbing. Sehingga ketika menginginkan hasil yang baik dan positif tentunya dibutuhkan kerja keras dari kedua belah pihak. Tidak bisa hanya mengandalkan salah satu pihak saja. Kedua belah pihak harus memiliki tujuan yang sama dan tingkat kerja keras yang sama pula untuk mendapatkan hasil yang maksimal.

Kebanyakan kasus terjadi adalah ketika peserta didik tidak berusaha sekeras apa yang dilakukan oleh pembimbing atau guru. Peserta didik terlihat lebih pasif atas apa yang sudah diberikan oleh guru atau pembimbing mereka, karena guru sudah pasti menemukan cara untuk menjadikan 
peserta didiknya termotivasi untuk memahami pembelajaran. Namun ada banyak sekali faktor yang menyebabkan hasil yang didapat tidak sesuai dengan hasil yang diinginkan. Tidak hanya faktor kesalahan salah satu pihak saja. Ada kalanya ketika lingkungan lah yang menjadi akar permasalahan. Seperti halnya perceraian orang tua yang mengakibatkan mental dan fikiran seorang peserta didik terganggu sehingga kehilangan fokus dan minat ketika proses pembelajaran berlangsung. Atau pada kasus lainnya, ketika seorang peserta didik tumbuh dengan ekonomi yang sangat minim sehingga tidak dapat memenuhi kebutuhannya dalam proses pembelajaran. Faktor yang terjadi akibat lingkungan ini tentu tidak dapat dihindari dan dikendalikan oleh peserta didik. Padahal mungkin saja niat yang dimiliki oleh peserta didik dan kondisi yang sedang ia rasakan saling bertolak belakang atau tidak dapat mendukung satu sama lain. Hal ini tentu sangat disayangkan. Pada hakikatnya setiap individu memiliki potensi minat dan bakat yang dapat dikembangkan. Hal yang harus dilakukan adalah mencari jalan keluar terbaik yang dapat mengatasi permasalahan karena faktor lingkungan tersebut dan semua pihak pun sudah seharusnya mendukung dan mengambil peran dalam memperbaiki permasalahan tersebut.

Hal yang sedang terjadi sekarang pada tahun 2020 pun sama halnya. Faktor lingkungan menjadi penghalang yang cukup besar bagi banyak masyarakat. Tak terkecuali proses pembelajaran yang melibatkan pembimbing dan juga peserta didik. Proses pembelajaran yang dilewati dengan banyak hambatan dan rintangan sedang dirasakan oleh banyak pihak. Namun tidak berhenti disitu, kini sudah banyak solusi-solusi yang diciptakan agar tetap dapat menunjang proses pembelajaran. Dengan dukungan teknologi yang canggih dan sudah maju di era sekarang sangatlah menolong banyak permasalahan yang terjadi seperti saat ini. Ketika aktivitas yang berhubungan dengan tatap muka dihentikan sementara, selalu ada solusi yang ditemukan. Masyarakat memanfaatkan kecanggihan teknologi jaman sekarang agar tetap dapat melakukan aktivitas tatap muka walaupun sedang dalam kondisi berjauhan bahkan ber mil-mil jauhnya. Begitu juga sama halnya dengan proses pembelajaran. Proses pembelajaran yang biasanya dilakukan dengan 
bertemu di kelas dan saling bertatap muka, kini dapat dilakukan dari rumah masing-masing dengan memanfaatkan teknologi yang ada.

\section{METODE PENELITIAN}

Menurut Sugiyono (2009:15), pengertian penelitian kualitatif adalah penelitian yang berlandaskan pada filsafat post positivisme, digunakan untuk meneliti pada kondisi obyek yang alamiah, (sebagai lawannya eksperimen) dimana peneliti adalah sebagai instrumen kunci, pengambilan sampel sumber data dilakukan secara purposive dan snowball, teknik pengumpulan dengan tri-anggulasi (gabungan), analisis data bersifat induktif atau kualitatif, dan hasil penelitian kualitatif lebih menekankan makna dari pada generalisasi.

Penelitian ini menggunakan metode penelitian kulitatif dengan indepth interview atau wawancara mendalam karena ingin megupas lebih dalam tentang apa yang dialami oleh beberapa mahasiswa upn veteran dalam pembelajaran daring pada masa pandemi covid-19. In-depth interview dilakukan secara online dari informan satu ke informan lainnya tanpa bertatap muka dikarenakan peraturan pemerintah yang mengharuskan tetap di rumah saja.
Metode pengumpulan data dalam penelitian ini adalah wawancara mendalam (in-depth interview). Wawancara mendalam merupakan proses menggali informasi secara mendalam, terbuka dan bebas. Kami sangat mengharapkan jika para responden dapat bekerja sama dengan kami sebagai peneliti agar tujuan atau goals dari jurnal ini dapat dicapai.Untuk itu kami sebagai peneliti akan memaksimalkan wawancara ini untuk menjadi bahan pengerjaan jurnal ini agar dapat bermanfaat bagi mahasiswa dan masyarakat khususnya mahasiswa yang melakukan kuliah secara online atau daring.

Pada tahap analisis data ini, peneliti akan memilah secara teliti data yang dapat dan tidak dapat dijadikan sebagai landasan utama sebelum disajikan dalampenelitian ini. Langkahlangkah yang digunakan pada tahap ini sebagai berikut:

1. Mencari responden yang melaksanakan perkuliahan secara daring

2. Responden yang memiliki pendapat tentang pandemi covid-19

3. Mahasiswa yang mengalami kendala dalam menggunakan aplikasi saat kuliah daring atau kuliah berbasis online. 
Teknik pengambilan data dilakukan dengan wawancara mendalam terhadap pihak responden dengan tujuan sebagai tolak ukur dalam membuat jurnal ini agar diperoleh data yang lengkap dan akurat serta dapat dipertanggung jawabkan adanya.

\section{HASIL DAN PEMBAHASAN}

Adanya faktor lingkungan yang mempersulit proses pembelajaran berlangsung seperti biasanya menjadikan setiap individu harus berfikir beberapa kali jauh kedepan agar menemukan cara yang tepat demi tetap berlangsungnya hak dan kewajiban yang harus dipenuhi oleh setiap individu. Solusi yang dilakukan dan digunakan oleh kebanyakan masyarakat di masa sulit seperti ini sejauh ini adalah memanfaatkan kecanggihan teknologi sebaik mungkin. Karena dalam keadaan yang sedang berjauhan sangat tidak mungkin untuk melakukan interaksi tanpa memanfaatkan teknologi yang ada. Beruntungnya teknologi yang ada pada masa sekarang sudah sangat membantu dan memumpuni kebutuhan individu. Tiap individu tetap dapat melangsungkan komunikasi dan interaksi meskipun beribu-ribu jarak memisahkan. Pun sudah banyak masyarakat yang sudah memahami bagaimana kinerja dari teknologi ini. Karena tentunya dalam menggunakan teknologi seseorang tidak dapat langsung mengerti. Dibutuhkan waktu untuk mencari informasi dan mempelajarinya.

Peneliti melakukan wawancara dengan jumlah 11 orang mahasiswa aktif yang ada di Surabaya dengan memilih mahasiswa dengan tiga kategori, yaitu mahasiswa yang grafik nilai nya memang bagus sejak awal masuk perkuliahan, kemudian mahasiswa yang tidak terlalu menonjol dalam nilai (nilai tidak tinggi dan tidak rendah) namun aktif di kelas, dan juga mahasiswa yang memiliki grafik nilai rendah pada perkuliahan, sehingga kami dapat membandingkan apakah permasalah yang dirasakan oleh mahasiswa ini hanya terjadi di sebagian orang saja atau dirasakan sama rata oleh semua pihak perserta didik.

Hasil yang kami peroleh mengatakan bahwa seluruh mahasiswa sedang merasakan berlangsungnya pembelajaran daring pada masa pandemi ini. Banyak sekali macammacam metode yang digunakan oleh dosen atau pembimbing dalam menjaga keberlangsungan proses pembelajaran bagi para mahasiswa. Tentunya segala 
usaha yang dilakukan menggunakan metode yang memanfaatkan teknologi atau internet. Ada yang menggunakan aplikasi yang memiliki fungsi seperti video call atau panggilan video dimana setiap partisipan dapat berbicara dan melihat wajah orang lain dalam perangkat yang digunakan. Aplikasi yang banyak digunakan sejauh ini menurut hasil wawancara adalah Zoom dan Google Meet. Aplikasi ini memberikan fasilitas dimana partisipan dapat melakukan share screen yang berarti siapapun dapat mengubah layar utama menjadi file yang dibutuhkan untuk kepentingan pembelajaran. Dapat dikatakan seperti pembelajaran dikelas yang biasanya dilakukan dosen dengan menggunakan bantuan bahan ajar seperti slide power point yang memudahkan mahasiswa atau peserta didik dalam memahami materi yang disampaikan. Baik aplikasi Zoom atau Google Meet memberikan fasilitas tersebut bagi yang menggunakan aplikasinya. Tentu saja hal tersebut sangat memberikan keuntungan bagi pembimbing atau dosen maupun peserta didik atau mahasiswa.

Aplikasi Zoom ada fasilitas yang dapat merekam semua percakapan yang dilakukan dari awal hingga akhir sehinnga dapat dipelajari berulangulang secara individu oleh peserta didik. Namun, di setiap kelebihan pasti memiliki kekurangan. Kekurangan yang dimiliki oleh aplikasi Zoom adalah host akan dikenakan biaya bila ingin menggunakan aplikasi diatas 40 menit. Zoom hanya memberikan akses free selama 40 menit. Jika ingin menggunakan aplikasi diatas 40 menit diharuskan untuk mengeluarkan biaya. Aplikasi Zoom juga memiliki kendala yang dimana tidak dapat melakukan sesi dengan partisipan diatas 100 orang. Sedangkan Google Meet memberikan akses paling banyak 250 orang dalam satu sesi. Beberapa narasumber yang kami wawancarai mengeluhkan hal tersebut sangat menggangu aktifitas pembelajaran yang sifatnya seperti kelas umum dengan banyak partisipan mahasiswa. Tidak semua mahasiswa dapat mengikuti sesi kelas. Dan ketika mendapat sesi yang berikutnya dosen dirasa pasti sudah lelah sehingga hak yang didapat mahasiswa pada sesi selanjutnya akan sedikit berbeda dengan mahasiswa yang mengikuti sesi pertama. Belum lagi karena maraknya penggunaan aplikasi Zoom di masa pandemi ini akhirnya bermunculan masalah dan isu-isu negatif. Beberapa orang yang memiliki niat buruk 
melakukan aksi jahatnya. Masyarakat yang menggunakan aplikasi Zoom pada smartphone nya dapat diretas oleh orang-orang jahat ini. Orang-orang jahat ini dapat mengetahui passwordsmartphone yang digunakan, semua file dan foto yang tersimpan di smartphone, password sosial media dan bahkan sampai m-banking. Walaupun hanya isu, tentu saja hal tersebut membuat banyak masyarakat khawatir.

Penggunaan teknologi basis internet, sudah pasti membutuhkan akses internet agar aplikasi dapat digunakan. Pembimbing dan peserta didik biasanya menggunakan alat teknologi seperti smartphone, laptop, atau ipad. Kebanyakan dosen atau pembimbing akan menggunakan laptop atau ipad karena dirasa dalam hal mengajar akan lebih mudah penggunaan laptop atau ipad ketimbang menggunakan smartphone. Mahasiswa juga beberapa menggunakan laptop atau ipad. Namun bagaimana kisahnya pada peserta didik yang tidak berkecukupan ekonomi untuk memiliki laptop atau ipad? Tentu saja memanfaatkan smartphone pribadi mereka masingmasing. Dan setiap smartphone pasti memiliki spesifikasi yang berbeda-beda. Dalam penggunaan alat-alat teknologi tersebut tentunya butuh yang namanya akses internet. Akses internet ini dapat dimanfaatkan hanya jika memiliki wifi atau kuota internet. Tentunya semua kases internet membutuhkan biaya. Terutama untuk melakukan aplikasi yang berbasis video call seperti Zoom atau Google Meet tentunya akan memakan internet yang sangat banyak.

Hal tersebut akan menjadi beban dan pikiran bagi peserta didik yang perekonomiannya tidak sebaik mereka yang mampu. Beruntungnya problema tersebut telah diatasi oleh pihak kampus. Kampus bertanggung jawab membantu mahasiswa yang merasa kesulitan biaya dalam pembelian kuota internet menurut narasumber yang kami wawancarai. Walaupun tetap dirasa kurang, namun mahasiswa tetap berterimakasih dan mengapresiasi hal tersebut karena dirasa cukup membantu kebutuhan para peserta didik dalam proses pembelajaran. Ternyata permasalahan tidak sampai disitu saja. Memiliki alat teknologi dan internet tidak menjadikan proses pembelajaran menjadi mudah. Karena koneksi internet di setiap tempat berbeda-beda. Ada yang daerah tempat tinggalnya memiliki koneksi internet yang sangat lancar. Terdapat daerah yang memiliki 
tingkat koneksi internet yang buruk. Permasalahan sinyal ini menyebabkan proses pembelajaran terhambat. Peserta didik tidak dapat dengan mudah memahami maksut dosen secara langsung karena terkadang video saat penjelasan materi macet karena koneksi yang kurang bagus.

Selain menggunakan teknologi berbasis video call, beberapa kampus menerapkan pembelajar daring melalui metode website resmi kampus. Namun menurut narasumber yang kami wawancarai metode tersebut dirasa kurang maksimal. Alasan yang diberikan oleh narasumber adalah situs web resmi memiliki tampilan yang kurang mudah seperti pada aplikasi Zoom atau Google Meet. Kemudian seringkali terjadi adanya kendala pada suara yang tidak muncul atau slide power point yang ditampilkan lemot atau nge hang. Beberapa dosen atau pembimbing yang sadar akan betapa beratnya mahasiswa menanggung beban biaya tambahan untuk pembelajaran daring memilih metode yang dirasa lebih menghemat kuota internet. Yaitu dengan menggunakan metode mengirimkan materi bahan ajar kepada para peserta didik melalui pesan elektronik. Pesan elektronik yang biasa digunakan adalah email, WhatsApp , dan Line grup. Beberapa dosen memilih hanya mengirimkan materi bahan ajar kepada peserta didik secara berkala. Ada juga dosen yang mengirim materi bahan ajar sekaligus suara yang direkam atau voice note yang berisi penjelasan lebih lengkap mengenai materi bahan ajar tersebut. Metode tersebut dianggap memudahkan mahasiswa dalam proses belajar. Meskipun tetap ada pertanyaanpertanyaan dari mahasiswa karena tetap belum dapat memahami maksud dosen. Beberapa dosen selalu tanggap dan sabar dalam memberikan penjelasan kepada peserta didik. Ada pula dosen atau pembimbing yang memberikan materi tidak dengan file atau penjelasan materi. Beberapa dosen ini menggunakan metode pemberian tugas yang sebelumnya materi tersebut belum dijelaskan kepada mahasiswa sehingga mahasiswa mengerjakan dengan usahanya sendiri. Metode ini dianggap sangat tidak efektif menurut narasumber karena banyak dari peserta didik yang bingung ketika mengerjakan dan berujung salah dalam pengerjaan tugas. Terutama ketika materi tersebut berhubungan dengan angka yang memang seharusnya materi diberikan kepada mahasiswa disertai penjelasan dosen. 
Beberapa tugas yang diberikan oleh dosen dilakukan dengan cara berkelompok. Tentunya dalam hal ini komunikasi yang baik pada kelompok sangat diperlukan. Tanpa adanya komunikasi yang baik tidak menutup kemungkinan pengerjaan tugas menjadi berntakan atau bahkan tugas tidak tersentuh sama sekali. Tentunya tidak ada dosen atau pembimbing yang menginginkan hal tersebut terjadi, karena memberian tugas oleh dosen pasti memiliki maksut dan tujuan yang baik kepada setiap peserta didik. Namun dengan situasi yang sedang berjauhan antara satu sama lain, tidak ada yang dapat diandalkan selain memanfaatkan teknologi yang ada. Komunikasi yang berlangsung pada setiap kelompok dilakukan dengan memanfaatkan aplikasi seperti WhatsApp dan Line. Menurut narasumber yang kami wawancarai, pengerjaan tugas kelompok dengan bantuan aplikasi tersebut sudah sangat membantu. Komunikasi dengan anggota kelompok menjadi terhambat ketika ada salah satu atau beberapa anggota yang tidak sedang dalam kondisi menggunakan smartphone nya. Hal tersebut menjadikan diskusi tidak semudah ketika diskusi dilakukan secara tatap muka. Beberapa individu akan merasa dirugikan karena kerja kelompok yang dilakukan tidak dapat berjalan dengan maksimal sehingga membutuhkan pengaturan waktu atau timing yang tepat ketika akan berdiskusi dengan anggota kelompok.

\section{SIMPULAN}

Dapat disimpulkan bahwa mahasiswa merasa kuliah secara tatap muka atau berada di kelas seperti biasanya dianggap lebih optimal dan penyampaian materi yang diberi dosen jauh lebih dapat diterima daripada perkuliahan secara online atau daring yang memiliki beberapa kendala dan hambatan bagi beberapa mahasiswa selama ini. Dikarenakan banyaknya hambatan atau kendala ini seharusnya pemerintah dapat menjadikan hal tersebut menjadi tolak ukur perkembangan pendidikan oleh pelajar khususnya mahasiswa di Indonesia.

Mahasiswa mengalami kendala atau jaringan yang tidak stabil saat kelas online mengaku sangat kesusahan dalam menyerap materi yang diberikan oleh dosen mengakiatkan tidak maksimalnya materi yang disampaikan oleh dosen serta beberapa mahasiswa kesulitan juga untuk mengerjakan tugas kelompok yang mengharuskan mahasiswa untuk memahami materi 
dengan baik ditambah lagi mahasiswa yang merasa kesulitan untuk menggunakan aplkasi meeting online untuk mengerjakan tugas kelompok.

Mahasiswa mengaku tidak selalu mengecek atau memegang handphone mereka karena sibuk bersama keluarganya, hal ini mengakibatkan terbuangnya waktu secara percuma hanya karena kendala ini, yang seharusnya pengerjaannya dapat diselesaikan tepat waktu malah menjadi molor dikarenakan beberapa mahasiswa yang tidak disiplin untuk mengerjakan tugas yang diberikan oleh dosen, alhasil tugas yang diselesaikan tidak mencapai goalsnya atau tidak dikerjakan secara maksimal dan dapat mempengaruhi nilai para mahasiswa tentunya.

Hal ini dapat mempengaruhi nilai mahasiswa dalam ujian akhir semester yang akan datang. Dikarenakan tidak tersampaikan materi dengan baik serta pengerjaan tugas yang kurang maksimal dihwatirkan mahasiswa mendapat nilai akhir atau IPK yang menurun pada tahun ini. Hal ini pun dapat mempengaruhi kualitas Universitas di beberapa daerah di Indonesia ini. Untuk itu perlu adanya kesadaran dari mahasiswa untuk meningkatkan proses pembelajarn diluar jam kelas, hal ini bertujuan untuk memaksimalkan pemahaman mahasiswa akan materimateri serta tugas-tugas yang diberikan oleh dosen agar dapat menjaga kestabilan nilai tiap mahasiswa.Berikut beberapa upaya yang dapat dilakukan mahasiswa dalam menjalankan kuliah daring atau online yaitu sebisa mungkin fokus dalam memahami materi yang disampaikan oleh dosen, jika ada kesalahan teknis atau jaringan yang tidak stabil, usahakan jangan panik dan tetap rileks dan menunggu hingga jaringan stabil dan dapat mengikuti perkuliahan kembali, setelah itu tanyakan pada teman jika ada poin-poin yang tidak dimengerti atau bisa mengadakan diskusi kelompok bersama teman-teman agar dapat lebh memahami materi, saat mengerjakan tugas kelompok, sebaiknya mahasiswa disiplin dalam mengerjakan dan bertanggung jawab untuk menyelesaikannya dengan baik. Begitulah upaya-upaya yang dapat dilakukan oleh mahasiswa selama menjalankan perkuliahan daring atau online. Upaya ini dilakukan bertujuan untuk mengurangi kendala mahasiswa dalam menjalanlan pekuliahan daring atau online. Diharapkan pandemi Covid-19 ini segera berlalu agar mahasiswa dan masyarakat luas dapat menjalankan aktivitasnya seperti biasa. 
Tetapi kita sebagai manusia hanya bisa berharap hal itu secepatnya bisa terjadi mengingat sudah banyaknya dampak yang terjadi akibat dari covid-19 ini.

\section{DAFTAR PUSTAKA}

Sugiyono. (2010). Metode Penelitian Pendidikan. Bandung: Alfabeta.

Wahyuni, Noor. (2014, Oktober 28). Indepth Interview (Wawancara Mendalam). Diakses dari https://qmc.binus.ac.id/2014/10/2 8/in-depth-interview-wawancaramendalam/

Pengertian Pembelajaran Menurut Para Ahli Terlengkap (2020, April 8). Diakses dari https://www.dosenpendidikan .co.id/pengertian-pembelajaranmenurut-para-ahli/

Penelitian Kualitatif (2020, Maret 8). Diakses dari https://www.dosenpendidikan.co.i d/penelitian-kualitatif/

Pane, Aprida. (2017). Belajar dan pembelajaran. FITRAH Jurnal Kajian Ilmu-Ilmu Keislaman, 3(2), 1-20 